\title{
LA BUENA FE EN LA ETAPA PRECONTRACTUAL*
}

\section{THE GOOD FAITH IN THE PRECONTRACTUAL STAGE}

Alejandro Borda**

Fecha de recepción: 1 de mayo de 2014 Fecha de aceptación: 30 de mayo de 2014

Disponible en linea: 30 de Julio de 2014

\section{Para citar este artículo/To cite this article}

\author{
Borda, Alejandro, La buena fe en la etapa precontractual, 129 Vniversitas, \\ 39-79 (2014). http://dx.doi.org/10.11144/Javeriana.VJ129.1bfe \\ doi:10.11144/Javeriana.VJ129.1bfe
}

* Trabajo original de investigación, que expone las reflexiones personales del autor sobre el tema.

** Abogado, Facultad de Derecho y Ciencias Sociales, Universidad de Buenos Aires, UBA y Doctor en Derecho Civil, UBA. En la actualidad, es profesor adjunto regular de contratos civiles y comerciales, Facultad de Derecho y Ciencias Sociales, UBA y profesor titular de contratos civiles y comerciales, Facultad de Derecho y Ciencias Políticas, Universidad Católica Argentina, UCA. Correo electrónico: aborda@reigadaborda.com.ar 


\section{RESUMEN}

El presente trabajo ha sido resultado de una amplia investigación acerca del principio de la buena fe y su importancia en el tráfico jurídico, en especial en la etapa precontractual de los negocios. Por medio de este artículo, se pretende demostrar la intrínseca relación que existe entre la buena fe, la moral y las buenas costumbres, para dejar claro el papel que cumple este principio como límite a los derechos subjetivos de las personas. Así mismo, la teoría del abuso del derecho es indispensable para llenar de contenido el principio de la buena fe, pues de ambos conceptos se derivan los deberes secundarios de conducta o deberes colaterales y la importancia de la culpa en la responsabilidad precontractual. Entonces, el principio de buena fe enriquece de valor la palabra y la promesa que lleva a las partes a negociar y le ayuda al juez a fallar en justicia y equidad.

Palabras clave: buena fe; deber secundario de conducta; pourparlers; culpa; responsabilidad; daño. 


\section{ABSTRACT}

The present work has been a result of a wide investigation about the good faith and its importance in the precontractual business's stage. This article demonstrate the intrinsic relationship between the good faith, morality and the good customs, making clear the role of the good faith as a limit to the people's subjective rights. Likewise, the abuse of law is very important for the concept of good faith, because both of them give rise to the collateral duties and the importance of the fault for the precontractual liability. In conclusion, the good faith represents the value of word for the contracting parties and this concept helps the judge to make decisions with fairness and equity.

Key words: Good faith; collateral duty; pourparlers; fault; liability; torts.

\section{SUMARIO}

INTRODUCCIÓN.- I. EL PRINCIPIO GENERAL DE LA BUENA FE. LA BUENA FE OBJETIVA Y LA BUENA FE SUBJETIVA.- II. EL PRINCIPIO GENERAL DE LA BUENA FE EN EL DERECHO ARGENTINO. EL ART. 1198 CC Y LOS PROYECTOS DE REFORMA.- III. EL PRINCIPIO GENERAL DE LA BUENA FE EN LA ETAPA PRECONTRACTUAL.- IV. LOS DEBERES SECUNDARIOS DE CONDUCTA.- V. El DERECHO DE NO CONTRATAR.VI. LA NEGOCIACIÓN CONTRACTUAL. LAS ETAPAS. TRATATIVAS PRELIMINARES O POURPARLERS. TRATATIVAS PRELIMINARES AVANZADAS. LA CARTA INTENCIÓN. Acuerdos de confidencialidad. Minuta. Punktation. Precontrato o ANTECONTRATO.- VII. LA REPARACIÓN POR LA RESPONSABILIDAD PRECONTRACTUAL. LAS TESIS DE IHERING Y FAGGELLA Y EL DERECHO ARGENTINO. Lo QUE DEBE INDEMNIZARSE. El FUNDAMENTO DE LA REPARACIÓN.- Bibliografía. 


\section{INTRODUCCIÓN}

El principio general de la buena fe es inagotable. Impregna la vida misma. Aparece una y otra vez en nuestras relaciones jurídicas y hasta meramente sociales. De alguna manera, dignifica a la persona humana pues presume que nos comportaremos con lealtad, de manera confiable.

Este principio, rico en contenido y valores, cubre las relaciones contractuales desde antes de que se celebre el contrato.

Justamente, este será el tema de nuestro estudio: el impacto del principio general de la buena fe durante la etapa precontractual, y las consecuencias del obrar abusivo y contrario al mentado principio. Empecemos.

\section{EL PRINCIPIO GENERAL DE LA BUENA FE. LA BUENA FE OBJETIVA Y LA BUENA FE SUBJETIVA}

El principio general de la buena fe es aquella norma jurídica que impone a las personas el deber de comportarse lealmente en el tráfico jurídico y ajustar el propio comportamiento al arquetipo de conducta social reclamado por la idea ética vigente ${ }^{1}$.

En esta exigencia de comportarse leal y éticamente quedan comprendidas obligaciones concretas que deben cumplir las personas que se relacionan jurídicamente. Esta relación se funda en la actitud positiva de cooperación que las partes deben exhibir, y en la necesidad de que las propias declaraciones despierten confianza en el otro ${ }^{2}$, lo que se alcanza manteniendo la palabra empeñada ${ }^{3}$. Y como consecuencia de ello, este comportamiento legal y ético, núcleo del principio general de la buena fe, opera como límite al ejercicio de los derechos subjetivos ${ }^{4}$.

1 Luis Díez-Picazo y Ponce de León, La doctrina de los propios actos, un estudio crítico sobre la jurisprudencia del Tribunal Supremo, 139, Bosch Casa Editorial, Barcelona (1963).

2 Rubén H. Compagnucci de Caso, Responsabilidad precontractual, Revista La Ley, 1001 (1985A).

3 Augusto Mario Morello \& Rubén S. Stiglitz, La doctrina del acto propio, Revista La Ley, 865 (1984-A).

4 Aurelia M. Romero-Coloma, Problemática de la buena fe en el ordenamiento jurídico, 54, 75, Editorial Tapia, Madrid (1990). 
Por otra parte, el principio general de la buena fe no se agota en una regla de conducta dirigida a las partes que se relacionan jurídicamente, sino que constituye una norma dirigida al juez, para que regularice — conforme a la equidad - la ejecución o la configuración de los negocios 5 .

Sin perjuicio de lo expresado precedentemente, hay coincidencia en considerar la "buena fe" como un concepto de difícil definición y aprehensión ${ }^{6}$, pero que - de todas maneras - ha tenido y tiene una enorme importancia en el mundo de las relaciones jurídicas.

En esta búsqueda de delimitar con la mayor precisión posible la noción de la buena fe, conviene distinguir entre las llamadas buena fe subjetiva y buena fe objetiva.

La buena fe subjetiva, también llamada buena fe en sentido psicológico o buena fe creencia, consiste en la creencia - nacida de un error excusable - de que la propia conducta no va contra derecho ${ }^{7}$. Este concepto engloba, en verdad, un doble campo de acción: en primer lugar, consiste en creer que no se está dañando un interés ajeno tutelado por el derecho o en ignorar que se estaba provocando tal daño - como ocurre, por ejemplo, con la posesión de buena fe-; en segundo lugar, consiste en la creencia o en el error de una persona, que genera un beneficio indebido en otro sujeto con quien se relaciona (como sucede, por ejemplo, con el pago de lo que no se debe $)^{8}$.

La buena fe objetiva, también llamada buena fe en sentido ético o buena fe lealtad, consiste en la creencia y en la confianza que tiene un sujeto en que una declaración surtirá en un caso concreto los mismos efectos que ordinaria y normalmente ha producido en casos iguales ${ }^{9}$. Son las reglas objetivas de la honradez en el comercio o en el tráfico ${ }^{10}$, que llevan a creer en la palabra empeñada y en que

5 Aurelia M. Romero-Coloma, Problemática de la buena fe en el ordenamiento jurídico, 54,75 , Editorial Tapia, Madrid (1990).

6 Luis Díez-Picazo y Ponce de León, La doctrina de los propios actos, un estudio crítico sobre la jurisprudencia del Tribunal Supremo, 134, Bosch Casa Editorial, Barcelona (1963).

7 Luis Díez-Picazo y Ponce de León, La doctrina de los propios actos, un estudio crítico sobre la jurisprudencia del Tribunal Supremo, 135, Bosch Casa Editorial, Barcelona (1963).

8 José Luis de Los Mozos, El principio de la buena fe, sus aplicaciones prácticas en el derecho civil español, 9, Bosch Casa Editorial, Barcelona (1965).

9 Guillermo A. Borda, Tratado de derecho civil, parte general II, 897, 14a ed., Guillermo J. Borda, actual., Editorial La Ley, Buenos Aires (2013).

10 Juan Ladaria-Caldentey, citado por Luis Díez-Picazo y Ponce de León, La doctrina de los propios actos, un estudio crítico sobre la jurisprudencia del Tribunal Supremo, 135, Bosch Casa 
el acto sea concertado lealmente ${ }^{11}$ y obrando con rectitud ${ }^{12}$. Con otras palabras, la buena fe objetiva es la exigencia de que las partes obren con honestidad, lealtad, transparencia y cooperación ${ }^{13}$.

Explicados estos dos aspectos de la buena fe, es posible destacar que:

a. Toda interpretación normativa debe ser acorde con el principio general de la buena fe, debiendo rechazarse todo resultado jurídico que se oponga a él.

b. Aun cuando el principio general de la buena fe tenga una función supletoria ${ }^{14}$, no solo deberá ser aplicado por el tribunal para resolver la litis, a falta de una norma específica ${ }^{15}$, sino que además, deberá teñir todas las resoluciones judiciales para no contrariar la costumbre y la ley natural.

\section{EL PRINCIPIO GENERAL DE LA BUENA FE EN EL DERECHO ARGENTINO. EL ART. 1198 CC Y LOS PROYECTOS DE REFORMA}

El principio general de la buena fe ha sido consagrado expresamente en el derecho positivo argentino en el art. 1198 del Código Civil, Ley 340 de 1869, luego de la reforma introducida por la Ley 17.711, el cual dispone: "los contratos deben celebrarse, interpretarse y ejecutarse de buena fe y de acuerdo con lo que verosímilmente las partes entendieron o pudieron entender, obrando con cuidado y previsión".

Editorial, Barcelona (1963).

11 Jorge Joaquín Llambías, Tratado de derecho civil, parte general II, 1552, Editorial Perrot, Buenos Aires (2012).

12 CÉsar CARlos Minoprio, El boleto de compraventa, el ejercicio abusivo del derecho y la prohibición de ir en contra de los propios actos, Revista del Notariado, 742, 1257 (1975, julio-agosto). Aurelia M. Romero-Coloma, Problemática de la buena fe en el ordenamiento jurídico, 54, 73, Editorial Tapia, Madrid (1990).

13 Marcos de Almeida Villaça-Azevedo, La buena fe objetiva y los deberes de ella derivados, en Tratado de la buena fe en el derecho, tomo II: doctrina extranjera y jurisprudencia, 129-154, 131, 3.4, Marcos M. Córdoba, dir., Editorial La Ley, Buenos Aires (2004).

14 Así parece desprenderse del art. 16 del Código Civil argentino, que dispone: "Si una cuestión civil no puede resolverse, ni por las palabras, ni por el espiritu de la ley, se atenderá a los principios de leyes análogas; $y$ si aún la cuestión fuere dudosa, se resolverá por los principios generales del derecho, teniendo en consideración las circunstancias del caso".

15 José Luis de Los Mozos, El principio de la buena fe, sus aplicaciones prácticas en el derecho civil español, 4, Bosch Casa Editorial, Barcelona (1965). 
Asimismo, el art. 1071 del mencionado cuerpo legal (reformado por la citada Ley 17.711), que incorpora el abuso del derecho, hace referencia también al principio que estamos estudiando. En efecto, dispone: "la ley no ampara el ejercicio abusivo de los derechos. Se considerará tal al que contraríe los fines que aquella tuvo en mira al reconocerlos o al que exceda los límites impuestos por la buena fe, la moral o las buenas costumbres".

El nuevo Código Civil y Comercial, Ley 26.994, promulgada el 7 de octubre de 2014 y que entrará en vigencia el 1 de enero de 2016 - el último de los cinco Proyectos de Reforma del Código Civil argentino presentados a partir del año 1987- es contundente respecto de que tanto el principio de la buena fe como del abuso del derecho son principios generales de aplicación a toda situación jurídica.

En efecto, ambos principios son incorporados en el Título preliminar, Capítulo 3, Ejercicio de los derechos, de la Ley 26.994. El art. 9 dispone: "los derechos deben ser ejercidos de buena fe". Y el art. 10, párrafo segundo, establece: "la ley no ampara el ejercicio abusivo de los derechos. Se considera tal el que contraría los fines del ordenamiento jurídico o el que excede los límites impuestos por la buena fe, la moral y las buenas costumbres".

Y volviendo sobre la buena fe, el art. 961 del nuevo Código dispone: "los contratos deben celebrarse, interpretarse y ejecutarse de buena fe. Obligan no solo a lo que está formalmente expresado, sino a todas las consecuencias que puedan considerarse comprendidas en ellos, con los alcances en que razonablemente se habría obligado un contratante cuidadoso y previsor".

En la misma línea, el Proyecto de 1987 — que fue sancionado por el Congreso Nacional pero vetado por el Poder Ejecutivodisponía: "los contratos deben celebrarse, ejecutarse y, cuando no correspondiere la interpretación restrictiva, interpretarse de buena fe y de acuerdo con lo que, verosímilmente, las partes entendieron, o pudieron entender obrando con cuidado y previsión" (art. 1197, párr. 2).

El Proyecto del Poder Ejecutivo de 1993, a su vez, establecía: "los contratos deben ser interpretados de acuerdo a la buena fe" (art. 930).

El Proyecto Federal de 1993 disponía: "los contratos deben celebrarse, ejecutarse e interpretarse de buena fe y de acuerdo con lo 
que, verosímilmente, las partes entendieron, o pudieron entender obrando con cuidado y previsión" (art. 1197, párr. 2).

Finalmente, el Proyecto de 1998 establecía: "el contrato debe ser interpretado de buena fe. En la aplicación de esta regla debe atenderse a lo dispuesto en el artículo 967...". Este artículo, en su párrafo 1, disponía: "El contrato obliga con los alcances en que razonablemente se habría obligado un contratante cuidadoso y previsor, incluyendo a las consecuencias virtualmente comprendidas en él, conforme a su naturaleza, a las negociaciones previas, a la conducta ulterior de las partes, a las prácticas establecidas entre ellas, a los usos si no han sido excluidos expresamente, y a la equidad, teniendo en cuenta la finalidad del acto y las expectativas justificadas de la otra parte". Y el art. 966 sancionaba: "las partes deben actuar de buena fe durante la celebración y ejecución del contrato".

Por tanto, en el derecho argentino, puede advertirse que - tanto en la ley vigente hasta el 31 de diciembre de 2015 como en los proyectos de reforma presentados y en la nueva Ley 26.994 que entra en vigor el 1 de enero de 2016 - el principio general de la buena fe configura una norma jurídica operante que debe ser usada no solo por quienes traban una relación jurídica, sino también - y de manera destacada - por los jueces, para hacer una interpretación del ordenamiento jurídico vigente, acorde con la justicia y la equidad. De esta manera, podemos percibir el estrecho vínculo que existe entre derecho y moral ${ }^{16}$.

\section{EL PRINCIPIO GENERAL DE LA BUENA FE EN LA ETAPA PRECONTRACTUAL}

Una lectura algo superficial de las normas vigentes en el derecho argentino, transcriptas en el parágrafo anterior, podría inducir a afirmar que en el régimen jurídico de mi país el comportamiento de buena fe solo es exigible a partir del momento en que se celebra el contrato, pues el art. 1198 del Código Civil — como se ha vistose refiere a la celebración, interpretación y ejecución del contrato.

Veremos que esto no es cierto.

16 Enrique Tomás Bianchi \& Héctor Pedro Iribarne, El principio general de la buena fe y la doctrina 'venire contra factum proprium non valet', Revista El Derecho, tomo 108, 851-862, 852. 
Pero antes, empecemos por analizar lo que ocurre en otros ordenamientos jurídicos, que solo se han de mencionar a título de ejemplo.

El Código Civil italiano dispone que las partes, en el desarrollo de las tratativas y en la formación del contrato, deben comportarse según la buena fe (art. 1337) ${ }^{17}$. Como se ve, la buena fe es exigible no solamente en el momento de la formación del contrato sino también durante el desarrollo de las tratativas previas; esto es, como se verá más adelante, en la etapa precontractual.

Incluso, el mismo código hace explícita la consecuencia de no comportarse de buena fe. En efecto, dispone que la parte que, conociendo o debiendo conocer la existencia de una causa de invalidez del contrato, no diere noticias de ella a la otra parte, será obligada a resarcir el daño que esta sufrió, por haber, sin culpa, confiado en la validez del contrato (art. 1338). No está de más señalar que el contrato, al ser declarado inválido, pierde sus efectos. La nulidad pronunciada por los jueces, por tanto, vuelve las cosas al mismo o igual estado en que se hallaban antes del acto anulado (conf. art. 1050, Código Civil argentino), lo que revela que al desaparecer - por así decir - el contrato, aquella confianza a la que se refiere el Código Civil italiano se genera en un tiempo que deviene precontractual ${ }^{18}$.

En esta misma línea, el Código Civil portugués establece que quien negocia con otro para cerrar un contrato, debe, tanto en las negociaciones preliminares como en la formalización de él, proceder según las reglas de la buena fe, bajo pena de responder por los daños que culposamente causare a la otra parte (art. 227, inc. 1$)^{19}$.

Lo mismo prevé el Código Civil peruano con una fórmula simple y clara: Los contratos deben negociarse, celebrarse y ejecutarse según las reglas de la buena fe y común intención de las partes $(\operatorname{art.} 1362)^{20}$.

17 Italia, Regio Decreto 262, 16 marzo 1942, Codice Civile. Disponible en: http://www.altalex. com/index.php?idnot $=34794$

18 Italia, Regio Decreto 262, 16 marzo 1942, Codice Civile. Disponible en: http://www.altalex. com/index.php?idnot $=34794$

19 Portugal, Decreto-Lei 47.344, de 25 de Novembro de 1966, Código Civil, actualizado até à Lei 59/99, de 30 de Junho de 1999. Disponible en: http://www.wipo.int/wipolex/es/details. jsp?id=7991

20 Perú, Decreto Legislativo 295, de 25 de julio de 1984, Código Civil. Disponible en: http://spij.minjus.gob.pe/CLP/contenidos.dll?f=templates\&fn=default-codcivil.htm\&vid=Ciclope:CLPdemo 
Los Principios Unidroit sobre los contratos comerciales internacionales, del Instituto Internacional para la Unificación del Derecho Privado, Unidroit, consagran la plena libertad para negociar los términos de un contrato y proclaman que no son responsables por el fracaso en alcanzar un acuerdo. Sin embargo, a renglón seguido, disponen que la parte que negocia o interrumpe las negociaciones de mala fe es responsable por los daños y perjuicios causados a la otra parte; y se preocupan en aclarar que se considera mala fe que una parte entre en negociaciones, o las continúe, cuando al mismo tiempo tiene la intención de no llegar a acuerdo alguno (art. 2.1.15) ${ }^{21}$.

Hasta acá, he mencionado solo algunos de los ordenamientos que expresamente se refieren al deber de comportarse de buena fe en la etapa anterior a la celebración del contrato. Pero, incluso, sistemas jurídicos que no se refieren de manera taxativa al deber de obrar de buena fe en la etapa precontractual, lo aceptan hoy.

En el derecho chileno, Hernán Corral-Talciani remarca la evolución que ha existido. Señala que antiguamente se sostenía que la responsabilidad nacía con la celebración del contrato, pues el art. 1546 del Código Civil de Chile ${ }^{22}$ se refiere solo a su ejecución. Más tarde, recuerda, se afirmó que si existía una promesa de contrato, la buena fe debía cubrir el período que va desde esa promesa hasta la efectiva celebración del contrato, pues en definitiva lo que ocurría era que el propio contrato de promesa debía ser ejecutado de buena fe. En la actualidad, sostiene, se exige a las partes que se comporten correctamente desde antes de celebrar el contrato e, incluso, cuando no haya habido contrato preliminar alguno, tal como ocurre en el caso paradigmático de los contratos de seguro médico ${ }^{23}$.

De lo expuesto, cabe afirmar que - sea porque la ley expresamente lo dispone; sea porque la doctrina y la jurisprudencia así lo han

21 Instituto Internacional para la Unificación del Derecho Privado, UNIDROIT, Principios Unidroit sobre los Contratos Comerciales Internacionales 2004. Disponible en: http://www. unidroit.org/spanish/principles/contracts/principles2004/blackletter2004.pdf

22 Chile, Decreto con Fuerza de Ley 1, 16 de mayo de 2000, Código Civil. Disponible en: http:// www.leychile.cl/Navegar?idNorma $=172986$

23 Hernán Corral-Talciani, La aplicación jurisprudencial de la buena fe objetiva en el ordenamiento civil chileno, en Tratado de la buena fe en el derecho, tomo II: doctrina extranjera y jurisprudencia, 205-224, 207, MARCos M. CórdoBA, dir., Editorial La Ley, Buenos Aires (2004). Versión actualizada disponible en: http://www.udp.cl/descargas/facultades_carreras/derecho/ pdf/investigaciones/Cuadernos_de_analisis_Coleccion_Derecho_Privado/N3_Temas_contratos/aplicacion_jurisprudencia_ordenamientocivilchileno_hernanCorral.pdf 
señalado - el principio general de la buena fe gobierna no solo el contrato ya celebrado sino también la etapa previa a su celebración.

Argentina, a pesar de que como he dicho al comienzo de este parágrafo no cuenta hoy con un texto que expresamente extienda los alcances de la buena fe a la etapa precontractual, no es la excepción: el período precontractual está gobernado por la buena fe.

En un recordado fallo, se ha resuelto que el ordenamiento jurídico protege las negociaciones tendientes a la celebración de un contrato. Por ello, aun antes de que se formalice, "el imperio del principio supremo de la buena fe penetra para siempre en el campo de la relación obligacional, inyectándole notas de respeto hacia los intereses de la contraparte, que se traducen en la necesidad de conducir el obrar de cada uno de un modo funcionalmente valioso, tipificado por los deberes de corrección”; deberes estos que, en el caso concreto, se tradujeron en la obligación de hablar claro y evitar, así, que la contraparte entienda mal la declaración ${ }^{24}$.

En otro caso, también antiguo, se sostuvo - con citas de Francesco Messineo y Jorge Mosset-Iturraspe — que la buena fe debe inspirar también la etapa de formación del contrato. Ello así, pues los que se acercan para conversar sobre un posible y futuro contrato, dan pie a un particular contrato social, basado en la recíproca confianza, que la ley no puede regular de una manera genérica y abstracta. De ahí el rol de la buena $\mathrm{fe}^{25}$.

Entonces, y aun ante la laguna legal, es claro que el deber de obrar de buena fe se expande a la etapa precontractual ${ }^{26}$. En esa etapa se viola el principio de la buena fe - más precisamente la buena fe objetiva, la que exige a las partes obrar con honestidad, lealtad, transparencia y cooperación - cuando se rompen las negociaciones en curso de manera abusiva, arbitraria o irrazonable. Conviene

24 Jurisprudencia de la Cámara Nacional en lo Civil Sala B, Könisberg vs. Almagro Construcciones S.A., 24 de septiembre de 1986. Lidia E. CAlegari De Grosso, El principio de la buena fe en relación con las nuevas formas de propiedad en las comunidades cerradas, en Tratado de la buena fe en el derecho, tomo I: doctrina nacional, 553-568, 563, MARCos M. Córdoba, dir., Editorial La Ley, Buenos Aires (2004).

25 Jurisprudencia de la Cámara Nacional en lo Civil, Sala F, Aldana-Acosta vs. CambaFernández, 14 de agosto de 1986. Claudio Marcelo KiPER, La buena fe y el sistema registral inmobiliario. El principio de la buena fe registral, en Tratado de la buena fe en el derecho, tomo I: doctrina nacional, 589-604, 589, Marcos M. CórdobA, dir., Editorial La Ley, Buenos Aires (2004).

26 Augusto H. L. Arduino, Culpa precontractual: condiciones para la generación de responsabilidad, Revista La Ley, 4, 365 (27 de marzo de 2012). 
recordar que - como se verá más adelante - es lícito interrumpir una negociación, con fundamento en la libertad de contratar; sin embargo, esa interrupción no puede ser abusiva, pues el art. 1071 del Código Civil argentino - antes transcripto- dispone que la ley no ampara el ejercicio abusivo de los derechos, y considera que hay abuso cuando se exceden los límites impuestos por la buena fe, la moral y las buenas costumbres.

No está de más señalar que la ya mencionada Ley 26.994, nuevo Código Civil y Comercial de la Nación, expresamente se refiere a esta cuestión. El art. 991 prevé: "Durante las tratativas preliminares, y aunque no se haya formulado una oferta, las partes deben obrar de buena fe para no frustrarlas injustificadamente. El incumplimiento de este deber genera la responsabilidad de resarcir el daño que sufra el afectado por haber confiado, sin su culpa, en la celebración del contrato".

En el mismo sentido, el Proyecto de 1987 disponía: "durante las tratativas preliminares, y aunque aún no se haya formulado una oferta, las partes están obligadas a comportarse de buena fe para no frustrarlas injustamente" (art. 1158). Exactamente, el mismo texto, también en el art. 1158, era previsto por el Proyecto Federal de 1993.

El Proyecto del Poder Ejecutivo de 1993 establecía: "durante las tratativas preliminares, las partes estarán obligadas a obrar de buena fe para no frustrarlas injustamente" (art. 871).

Y el Proyecto de 1998, por último, disponía: "las partes deben comportarse de buena fe para no frustrar injustamente las tratativas contractuales, aunque todavía no haya sido emitida una oferta. El incumplimiento de este deber genera responsabilidad por daño al interés negativo" (art. 920).

Si bien será una cuestión que desarrollaré más adelante, parece oportuno destacar la mayor precisión que tiene este último Proyecto respecto de la Ley 26.994, con relación al daño resarcible. Mientras el Proyecto de 1998 pone de relieve que el daño resarcible, provocado por el apartamiento injusto de las tratativas, es al interés negativo; la Ley 26.994 se limita a decir que debe resarcirse el daño que sufra el afectado por haber confiado, sin su culpa, en la celebración del contrato. Se trata, esta última, de una norma de una textura desmedidamente abierta que impide conocer de antemano el costo de no continuar con las tratativas. 


\section{LOS DEBERES SECUNDARIOS DE CONDUCTA}

Los deberes colaterales o secundarios de conducta se derivan de la buena $\mathrm{fe}^{27} \mathrm{y}$ abarcan no solo el período contractual sino que se expanden a la etapa precontractual e, incluso, a la poscontractual ${ }^{28}$. De alguna manera, estos deberes secundarios de conducta hacen explícita la aplicación del principio general de la buena fe a las relaciones jurídicas.

Estos deberes colaterales pueden estar explícitamente incorporados en la relación contractual (por voluntad de las partes o por aplicación de la ley) o no. Y es importante destacar que, aun en el caso de que no estén incorporados al contrato, existen y que ellos permiten ampliar las reglas de conducta exigibles a las partes, más allá de la mera literalidad contractual ${ }^{29}$.

En efecto, hay deberes implícitos que derivan del principio cardinal de la buena fe. Así, sostiene Atilio Aníbal Alterini, es preciso hablar claro, debe descartarse la reserva mental, es importante considerar la conducta de las partes contratantes, debe tenerse en cuenta la condición personal de quienes celebran el contrato (esto es, considerar si se trata de hombres de negocios, profesionales o iletrados), deben interpretarse restrictivamente las cláusulas de caducidad, las liberalidades y la facultad de rescisión unilateral, etc. ${ }^{30}$

Estos deberes implícitos no solo existen cuando se ha celebrado un contrato, sino también antes de su celebración, como dije al comienzo de este parágrafo. Me detendré en cuatro deberes implícitos que merecen ser destacados en la etapa precontractual: los de información, seguridad, confidencialidad y custodia.

1. Por el deber de información, el oferente está obligado a poner al alcance del destinatario de la oferta el conocimiento adecuado, claro y preciso sobre hechos relativos al contrato que se pretende celebrar, circunstancias o condiciones que puedan tener aptitud

27 Noemí Lidia Nicolau, María del Pilar Hernández, Ariel Ariza \& Sandra Analía Frustagli, Fundamentos de derecho contractual, I, 248, Editorial La Ley, Buenos Aires (2009).

28 Ricardo Luis LorenzetTi, Esquema de una teoría sistémica del contrato, La Ley, tomo 1999-E, 1168-1185, sección Doctrina, Buenos Aires (diciembre de 1999).

29 Atilio Aníbal Alterini, Los pilares del contrato moderno, 10 Revista de Responsabilidad Civil y Seguros, 5, 3-19 (2008).

30 Atilio Aníbal Alterini, Contratos civiles, comerciales, de consumo: teoría general, 65, Editorial Abeledo-Perrot, Buenos Aires (1998). 
para influir sobre la decisión a tomar. Para destacar la necesidad de cumplir este deber de manera adecuada y veraz, se ha dicho que si alguna información relativa a determinadas condiciones del negocio, que es dada durante la etapa precontractual, fuera errónea o incompleta, esa condición no podrá ser agregada al contrato proyectado, ni este podrá contrariar en sus cláusulas la información dada en aquella etapa ${ }^{31}$.

El Anteproyecto de Código Europeo de contratos de la Academia de Pavía regula con precisión este deber de información en su artículo 7, y dispone: "1. En el curso de las tratativas, cada una de las partes tiene el deber de informar a la otra sobre cada circunstancia de hecho y de derecho de la que tenga conocimiento, o de la que deba tener conocimiento, y que permita a la otra darse cuenta de la validez del contrato y del interés en concluirlo. 2. En caso de omisión de información o de información falsa o reticente, si el contrato no es concluido o está viciado de nulidad, la parte que obró contra la buena fe es responsable ante la otra en la medida prevista por el artículo 6 , inciso $4^{32}$. Si el contrato fue concluido, debe restituir la suma o abonar la indemnización que el juez estime conforme a la equidad, salvo el derecho de la otra parte de atacar el contrato por dolo o error".

Algo más cabe señalar. El contenido de este deber de información se ha expandido de alguna manera. Hoy, no basta con aclarar cuestiones o informar sobre determinadas situaciones, sino que, con fundamento en esta obligación, debe asesorarse o aconsejarse a la otra parte sobre la conveniencia o no de concertar el negocio.

2. Por el deber de seguridad, una de las partes garantiza que la otra no sufrirá ningún daño (en su persona o en sus bienes) a raíz de la actividad o servicio realizado; se trata de un deber de prevención pero que se traduce en una obligación de reparar el daño si este finalmente ocurre, y que recae sobre quien se considera está

31 Marcos de Almeida Villaça-Azevedo, La buena fe objetiva y los deberes de ella derivados, en Tratado de la buena fe en el derecho, tomo II: doctrina extranjera y jurisprudencia, 129-154, 131, 3.4.1, Marcos M. Córdoba, dir., Editorial La Ley, Buenos Aires (2004).

32 Norma que dispone que debe reparar (i) el daño sufrido por la otra parte, en la medida de los gastos contraídos por esta última durante las tratativas hechas en vista de la celebración del contrato, y (ii) la pérdida de oportunidades similares causada por las tratativas pendientes. 
en mejor condición para prevenir ${ }^{33}$. Si bien el daño se producirá después de celebrado el contrato, este se ha formalizado, entre otros motivos, por la seguridad dada previamente de que no se sufriría perjuicio alguno.

3. Por el deber de confidencialidad (que muchas veces se acuerda de manera expresa e, incluso, por medio de un convenio autónomo), las partes que han entrado en negociaciones se obligan a mantener en secreto la información sensible recibida, excepto que se haya autorizado su divulgación.

El ya mencionado Anteproyecto de la Academia de Pavía llama a este deber de confidencialidad como deber de reserva y dispone en el art. 8: "1. Las partes tienen el deber de hacer un uso reservado de las informaciones obtenidas confidencialmente en el transcurso de las tratativas. 2. La parte que no respeta este deber está obligada a reparar el daño sufrido por la otra y, si además obtuvo una ventaja indebida de la información confidencial, debe indemnizar a la otra parte en la medida de su propio enriquecimiento".

También los Principios Unidroit destacan este deber de confidencialidad y establecen: "Si una de las partes proporciona información como confidencial durante el curso de las negociaciones, la otra tiene el deber de no revelarla ni utilizarla injustificadamente en provecho propio, independientemente de que con posterioridad se perfeccione o no el contrato. Cuando fuere apropiado, la responsabilidad derivada del incumplimiento de esta obligación podrá incluir una compensación basada en el beneficio recibido por la otra parte" (art. 2.1.16).

Como puede advertirse, se procura evitar la divulgación de la información que se haya obtenido a causa de la negociación y mientras su difusión pueda originar perjuicios a la otra parte.

La ya citada Ley 26.994 también prevé de manera expresa este deber, al disponer en su artículo 992: "si durante las negociaciones, una de las partes facilita a la otra una información con carácter confidencial, el que la recibió tiene el deber de no revelarla y de no usarla inapropiadamente en su propio interés". Y añade: "La parte que incumple este deber queda obligada a reparar el daño sufrido

33 Atilio Aníbal Alterini, Contratos civiles, comerciales, de consumo: teoría general, 330, 589, Editorial Abeledo-Perrot, Buenos Aires (1998). 
por la otra y, si ha obtenido una ventaja indebida de la información confidencial, queda obligada a indemnizar a la otra parte en la medida de su propio enriquecimiento".

4. Por el deber de custodia, quien recibe una cosa para observarla o realizar sobre ella ensayos o pruebas, debe guardarla y custodiarla, de manera de reintegrarla íntegra y en perfecto estado. Claramente, estamos en la etapa precontractual pues el ensayo o prueba se realiza antes de celebrar el contrato y justamente para determinar la conveniencia o no de su celebración.

La ley argentina, por su parte, incluye explícitamente algunos deberes colaterales. Así, impone al vendedor el deber de conservar la cosa tal como se hallaba el día del contrato (art. 1408, Código

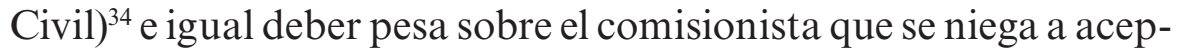
tar el encargo (art. 236, Código de Comercio) ${ }^{35}$; el empresario debe comunicar al dueño de la obra la mala calidad de los materiales provistos (art. 1630, Código Civil); el corredor debe guardar secreto de todo lo concerniente a las negociaciones que se le encarguen (art. 36 , inc. f, Ley $20.266^{36}$, reformada por Ley $25.028^{37}$ ); el enajenante a título oneroso debe cooperar con su cocontratante defendiéndolo en juicio cuando este sea demandado por evicción (art. 2108, Código Civil); el transportista debe cumplir puntualmente con la entrega de la cosa transportada (art. 187, Código de Comercio), etc.

Estos deberes secundarios de conducta, de origen convencional, legal, o derivados implícitamente del principio general de la buena fe, son clasificados por Ricardo Luis Lorenzetti, según la finalidad que persiguen ${ }^{38}$.

Califica como deberes de finalidad negativa a aquellos que procuran impedir invasiones arbitrarias en la esfera íntima de las partes

34 Ley 340, 25 de septiembre de 1869, Código Civil. Disponible en: http://www.infoleg.gov.ar/ infolegInternet/anexos/105000-109999/109481/texact.htm

35 Ley 2.637, 1 de mayo de 1890, Código de Comercio. Disponible en: http://www.infoleg.gov.ar/ infolegInternet/anexos/105000-109999/109500/texact.htm

36 Ley 20.266, 10 de abril de 1973, Martilleros, condiciones habilitantes. Disponible en: http:// www.infoleg.gob.ar/infolegInternet/verNorma.do?id=56724

37 Ley 25.028, 1 de diciembre de 1999, Régimen legal de martilleros y corredores. Disponible en: http://infoleg.mecon.gov.ar/infolegInternet/verNorma.do?id=61719

38 RicArdo Luis LorenzetTi, Esquema de una teoría sistémica del contrato, La Ley, tomo 1999-E, 1168-1185, sección Doctrina, Buenos Aires (diciembre de 1999). 
contratantes; los deberes de finalidad positiva son los que tienden a favorecer el cumplimiento del contrato. Un ejemplo de los primeros es el de seguridad; entre los segundos puede mencionarse al deber de información.

Cabe preguntarnos ahora, jes suficiente reconocer la existencia de estos deberes?, ¿basta con ello? De ninguna manera. Es necesario prevenir el incumplimiento de tales deberes y, en su caso, resarcir los daños causados.

Aun a riesgo de excederme de los límites de este trabajo, me parece necesario hacer un breve apunte respecto de este deber de prevención.

Si de prevenir se trata, es preciso referirse a la tutela inhibitoria, figura esta que excede largamente el marco de la tradicional medida cautelar que solo tiende a asegurar a una de las partes el derecho cuyo reconocimiento se pretende obtener en un proceso distinto ${ }^{39}$. La tutela inhibitoria tiene una finalidad preventiva pues procura evitar la producción de un daño que bien puede ser causado por una relación contractual e, incluso, antes de la instrumentación del contrato. Esta tutela apunta a preservar bienes infungibles, derechos fundamentales (como la salud, la intimidad o la identidad personal) que aún no han sido dañados pero que sí están amenazados por una actividad continuada, por actos repetitivos o por la inminencia de un acto ilícito, que pueden ser detenidos ${ }^{40}$.

El objetivo último que se persigue es proteger los bienes y derechos que se gozan. Esta protección ha sido fuertemente impulsada en el derecho argentino, a partir de la reforma constitucional de $1994^{41}$ que ha impuesto a las autoridades la obligación de proteger la salud, la seguridad e intereses económicos, ha reconocido el derecho de las personas a recibir una información adecuada y veraz, condiciones de trato equitativo y digno, y a la libertad de elección (art. 42), y ha otorgado al sujeto el derecho a interponer acción de amparo contra actos de autoridades públicas o de particulares que en forma actual o inminente restrinjan, alteren o amenacen

39 Raúl Martínez-Botos, Medidas cautelares, 27, Editorial Universidad, Buenos Aires (1996).

40 Ricardo Luis Lorenzetti, Consumidores, 434, Editorial Rubinzal-Culzoni, Santa Fe (2003).

41 Constitución de la Nación Argentina, 22 de agosto de 1994. Disponible en: http://www.senado. gov.ar/bundles/senadoparlamentario/pdf/institucional/constitucion_nacional_argentina.pdf 
derechos reconocidos por la Constitución, los tratados o la misma ley $(\operatorname{art} .43)^{42}$.

Ahora, cuando no se ha podido prevenir el daño y este se ha producido, llegará el momento de resarcirlo, sea reparando el daño provocado, sea indemnizando, y sin importar en qué lugar del íter contractual nos encontremos, pues la reparación, si bien con distinta intensidad, ocurrirá en las etapas precontractual, contractual y poscontractual.

\section{EL DERECHO DE NO CONTRATAR}

Cuando se hace referencia a la formación del contrato, es ineludible referirse al principio de la libertad. Todo sujeto es libre de contratar o de no contratar; y, en el caso de querer contratar, de elegir con quién hacerlo y de determinar su contenido.

En lo que acá interesa, es necesario poner de relieve esa libertad de no contratar, que está comprendida en el art. 910 del Código Civil argentino cuando establece: "nadie puede obligar a otro a hacer alguna cosa, o a restringir su libertad, sin haberse constituido un derecho especial al efecto"43.

En otras palabras, como regla nadie puede ser obligado a contratar.

La cuestión a dilucidar es si esa regla sigue vigente o no cuando dos o más personas han entrado en negociaciones, que avanzan regularmente. En este caso, ¿es lícito desistir la negociación emprendida?

Enseña Guillermo A. Borda que en la vida de los negocios se demuestra que muchas veces las tratativas previas a los contratos,

42 Así se ha hecho lugar a la acción de amparo promovida contra una obra social, disponiéndose que esta última debía mantener los beneficios asistenciales que daba a la amparista, en su calidad de cónyuge del titular, ahora fallecido, pues en un tema tan delicado como la salud, el peligro en la demora se ha verificado por la muerte del titular de la afiliación y la negativa ya exteriorizada por la obra social frente al pedido que la amparista formuló para recuperar su condición de afiliada, con la consiguiente incertidumbre acerca de la continuidad de los servicios médico asistenciales con que contaba hasta ese momento. Jurisprudencia de la Cámara Nacional de Apelaciones en lo Civil y Comercial Federal, Sala 2, A. M. H. vs. Obra Social de la Unión del Personal Civil de la Nación s/inc. de apelación de medida cautelar, 27 de diciembre de 2012, 253, El Derecho, 307.

43 Una excepción clara a este principio de la libertad de no contratar, en Argentina, puede verse en la contratación obligatoria del seguro de responsabilidad civil por parte de los titulares de dominio de automotores (Ley 24.449, Art. 68). Ley 24.449, 23 de diciembre de 1994, Ley de Tránsito. Disponible en: http://www.infoleg.gob.ar/infolegInternet/anexos/0-4999/818/texact.htm 
sobre todo si estos son importantes, suponen gestiones, trabajos y gastos. Y añade que, como regla, tales trabajos corren por cuenta de la parte que los ha hecho, pues actúa en su propio interés y asume por propia determinación el riesgo del fracaso de las tratativas, ya que la otra parte no ha dado todavía su consentimiento. En principio, entonces, el desistimiento de las negociaciones previas es perfectamente legítimo y no puede dar origen a una indemnización ${ }^{44}$.

En este orden de ideas, el nuevo Código Civil y Comercial o Ley 26.994 dispone: "las partes son libres para promover tratativas dirigidas a la formación del contrato, y para abandonarlas en cualquier momento" (art. 990).

La solución es lógica pues, de lo contrario, las meras tratativas preliminares tendrían efectos similares al contrato mismo, lo que constituye un sinsentido.

Lo expuesto precedentemente no es óbice para afirmar que quien inicia voluntariamente tratativas preliminares con el objetivo de celebrar un contrato, debe responder por los daños que pueda provocar su apartamiento arbitrario, doloso e incluso culposo de la negociación ${ }^{45}$. No es que esté obligado a celebrar el contrato; pero sí está obligado a resarcir el daño causado. La buena fe que debe presidir los negocios jurídicos no permite ya una ruptura irrazonable, sin causa, arbitraria, de las tratativas, y obliga a reparar los perjuicios causados ${ }^{46}$. Admitir ese apartamiento arbitrario implicaría consagrar la validez de conductas abusivas, en clara violación de la regla establecida en el art. 1071 del Código Civil argentino ${ }^{47}$, que justamente obliga a ejercerlos de manera regular y dispone expresamente que la ley no ampara su ejercicio abusivo, como ya se ha visto (apartado II).

44 Guillermo A. Borda, Tratado de derecho civil. Obligaciones II, 1226, $10^{\text {a }}$ ed. Alejandro Borda, actual., Editorial La Ley, Buenos Aires (2012).

45 RicARdo L. LoREnZETTI, La responsabilidad precontractual como atribución de los riesgos de la negociación, Revista La Ley, 716 (1993-B).

46 Augusto H. L. Arduino, Culpa precontractual: condiciones para la generación de responsabilidad, Revista La Ley, II, 365 (27 de marzo de 2012).

47 Jurisprudencia de la Cámara Nacional en lo Civil, Sala A, Soria Luis Santos vs. Jet Paq S.A., 27 de diciembre de 2011. Jurisprudencia Argentina, n. ${ }^{\circ}$ 4, 72 (2012-II). 


\section{LA NEGOCIACIÓN CONTRACTUAL. LAS \\ ETAPAS. TRATATIVAS PRELIMINARES \\ O POURPARLERS. TRATATIVAS \\ PRELIMINARES AVANZADAS. LA \\ CARTA INTENCIÓN. ACUERDOS DE \\ CONFIDENCIAlidad. Minuta. PUNKTATION. PRECONTRATO O ANTECONTRATO}

A. En la vida diaria, los contratos se celebran sin una negociación previa. En efecto, la compra de mercadería en un supermercado o en un kiosco o en una librería, o de un pasaje en cualquier medio de transporte o de una entrada para un espectáculo público, entre otros muchísimos ejemplos que podrían citarse, no requieren una negociación previa. Basta conocer el precio y pagarlo.

Pero otros contratos, quizás los que individualmente tengan una mayor importancia económica, necesitan esta negociación, que podrá llevar finalmente a concretar su celebración, o no. La contratación de un servicio profesional, la compra de un inmueble, la concertación de un contrato de larga duración, por dar algunos casos, necesitan esa negociación previa, que podrá permitir alcanzar una declaración de voluntad común, diferente de la voluntad individual de cada parte al inicio de la negociación, destinada a reglar sus derechos, como define al contrato el art. 1137 del Código Civil argentino.

Por eso, se puede decir que cuando se trata de estudiar el contrato hay básicamente dos etapas: la primera, que abarca todos los actos que pueden realizarse durante el período previo a la celebración del contrato, que llamaremos las tratativas preliminares; y, la segunda, que comienza con la celebración del contrato y llega hasta su plena ejecución.

En la etapa anterior a la celebración del contrato, pueden distinguirse, a su vez, dos períodos. Uno que va desde el inicio de las tratativas hasta la oferta, y en el que las partes discuten e intercambian ideas, buscan información, proyectan y analizan cláusulas que pueden incluirse en el futuro contrato; otro, a partir de la oferta, en adelante. 
Ese primer período, en el que se prepara el terreno para hacer la propuesta, se lo llama "tratatives", "pourparlers", "tratativas precontractuales" o "tratativas preliminares", y en él pueden darse conversaciones sobre aspectos circunstanciales o secundarios pero sin que esté presente la verdadera esencia contractual ${ }^{48}$.

Durante todo este período, las partes deben (i) obrar de manera acorde con la buena fe objetiva (a la que me he referido más arriba, apartado I), (ii) mantener el secreto sobre todo lo que sea confidencial, (iii) dar la información necesaria, (iv) mantener y conservar los elementos materiales que resultan el sustrato del futuro acuerdo ${ }^{49}$, aspectos - estos tres últimos - que hemos analizado como deberes secundarios de conducta. Además, no pueden abandonar los tratos de manera abrupta y sin causa ${ }^{50}$.

Este último de los aspectos reseñados es el más complejo. Por un lado, no es admisible un obrar contrario a la buena fe, como lo sería la ruptura intempestiva de la negociación, pero por otro lado debe resguardarse la libertad de contratar, que permite, finalmente, contratar o no contratar. Si bien hay cierto margen de discrecionalidad para abandonar las tratativas, no es admisible que se las abandone de manera dolosa, culposa o de mala fe, como ocurriría si se alegasen circunstancias que se conocían al momento de iniciar la negociación ${ }^{51}$.

El anteproyecto de código europeo de contratos de la Academia de Pavía, en su artículo 6, se hace cargo de esta cuestión, bajo el título deber de corrección. Dispone: "cada una de las partes es libre para emprender tratativas con vistas a concluir un contrato sin

48 Rubén H. Compagnucci de Caso, Responsabilidad precontractual (Desarrollo general del tema), Revista La Ley, III, 1380 (2006-E).

49 Compagnucci de Caso señala que este deber de mantener y conservar los elementos materiales se ubica en el marco de la responsabilidad precontractual y da el ejemplo del deterioro causado por uno de los futuros contratantes, al revisar la cosa. RuBÉN H. CoMPAGNUCCI DE CAso, Responsabilidad precontractual (Desarrollo general del tema), Revista La Ley, IV, 1380 (2006-E). El tema genera algunas dudas pues también puede afirmarse que se trata de un simple supuesto de responsabilidad del depositario. Cabe recordar que en la ley argentina hay depósito cuando una de las partes se obliga a guardar gratuitamente una cosa mueble o inmueble que la otra le confía, y a restituir la misma e idéntica cosa (art. 2182). Por esto, bien podría afirmarse que hay un contrato de depósito preliminar al contrato definitivo que se está negociando.

50 Rubén H. Compagnucci de CAso, Responsabilidad precontractual (Desarrollo general del tema), Revista La Ley, IV, 1380 (2006-E).

51 Rubén H. Compagnucci de CAso, Responsabilidad precontractual (Desarrollo general del tema), Revista La Ley, X, 1380 (2006-E). 
que se le pueda imputar ninguna responsabilidad en caso de que el contrato no sea celebrado, salvo si su comportamiento es contrario a la buena fe" (inc. 1). Explica que actúa contra la buena fe (i) "la parte que comienza o prosigue tratativas sin intención de llegar a la conclusión del contrato" (inc. 2) y (ii) la parte que interrumpe las tratativas sin motivo justificado y cuando ya se han examinado los elementos esenciales del contrato cuya celebración eventual prevén, y siempre que se hubiera suscitado en la otra parte una confianza razonable en cuanto a la estipulación del contrato (inc. 3). En estos casos, "la parte que obró contra la buena fe debe reparar el daño sufrido por la otra parte, en la medida de los gastos contraídos por esta última durante las tratativas hechas en vista de la celebración del contrato, así como la pérdida de oportunidades similares causada por las tratativas pendientes" (inc. 4).

El Anteproyecto de la Academia de Pavía recepta así la tesis referida del resarcimiento del daño al interés negativo, que veremos más adelante (apartado VII).

B. La jurisprudencia y la doctrina han comenzado a diferenciar entre tratativas preliminares y tratativas preliminares avanzadas. En las primeras, como se ha visto, hay deberes (los de información, seguridad, confidencialidad, custodia) en cabeza de ambas partes que si se violan deben ser reparados. Pero cuando se habla de tratativas preliminares avanzadas, se hace hincapié en la necesidad de no romper intempestivamente, sin justificación alguna y de manera incausada la negociación que, por su desarrollo, ha permitido generar en las partes una confianza cierta de que el negocio se formalizará. Y su frustración genera una responsabilidad precontractual, si culmina en daño ${ }^{52}$.

Como puede advertirse, esta denominada responsabilidad precontractual no deriva de la obligación de celebrar un contrato futuro (obligación que no existe), sino de la injusta frustración de las tratativas contractuales avanzadas ${ }^{53}$, que perjudica los intereses de la contraparte ${ }^{54}$.

52 Rubén S. Stiglitz, Contratos civiles y comerciales. Parte general I, 134, 2a ed., Editorial La Ley, Buenos Aires (2010).

53 Jurisprudencia de la Cámara Nacional en lo Comercial, Sala E, Transportes Cadam S.A. vs. Coca-Cola FEMSA, 19 de octubre de 2006. Jurisprudencia Argentina, n. ${ }^{\circ}$ 3, 82 (2007-II).

54 Rubén S. Stiglitz, Contratos civiles y comerciales. Parte general I, 134, $2^{\text {a }}$ ed., Editorial La 
Esa confianza cierta no es un mero dato subjetivo de la persona que la alega, sino que ella debe resultar objetivamente de los actos que el conegociador haya realizado. Como se ha dicho, el conegociador que alega la responsabilidad precontractual debe acreditar hechos o conductas de su contraparte susceptibles de generar esa confianza o expectativa y, por supuesto, para su configuración debe tomar elementos objetivos, es decir, valorables por sí mismos ${ }^{55}$.

C. Durante la etapa precontractual, durante las tratativas preliminares, las partes suelen celebrar ciertos acuerdos, que sin llegar a constituir un contrato, generan ciertas consecuencias.

El primero de estos acuerdos es la denominada carta intención. La carta intención es el instrumento mediante el cual una parte, o todas ellas, expresan su consentimiento para negociar sobre ciertas bases, limitado a cuestiones relativas a un futuro contrato (conf. art. 993, nuevo Código Civil y Comercial, Ley 26.994). La voluntad exteriorizada en una carta de intención se halla dirigida a producir un efecto provisorio que se agota en la preparación del contrato, no constituyendo por sí el instrumento de un contrato ni obliga a quien la emite ${ }^{56}$. Claramente, entonces, la carta intención no configura un contrato y ni siquiera constituye una oferta.

Pero que no haya contrato, ni una oferta, no significa que se pueda interrumpir la negociación de manera intempestiva o abusiva. En efecto, como regla, la ruptura unilateral de las negociaciones habilitadas por una carta de intención constituye un supuesto de responsabilidad precontractual, que puede generar — si es abusiva - el derecho en cabeza de la contraparte a reclamar el daño sufrido, a menos que se hubiera pactado en la carta de intención, de manera expresa, que la falta de acuerdo de voluntades en cuanto a la suscripción del contrato "definitivo", no generará derecho a reclamo alguno por ningún concepto a favor de ninguna de las partes. Se trataría de una cláusula de irresponsabilidad, que deter-

Ley, Buenos Aires (2010).

55 Iván G. Di Chiazza \& Pablo Augusto van Thienen, Tratativas precontractuales: delimitación de la figura, Revista La Ley, III, 588 (2012-B).

56 Jurisprudencia de la Cámara Nacional en lo Comercial, Sala D, Neptan S.A. vs. International Container Terminal Services y otros, 17 de febrero de 2010. Jurisprudencia Argentina, n. ${ }^{\circ} 2$, 65 (2010-III). Rubén S. Stiglitz, Contratos civiles y comerciales. Parte general I, 177, $2^{\mathrm{a}}$ ed., Editorial La Ley, Buenos Aires (2010). 
mina la improcedencia de todo reclamo indemnizatorio incluso por la falta de preaviso ${ }^{57}$.

D. Uno de los acuerdos que suelen celebrarse durante esta etapa de las tratativas preliminares es el llamado convenio de confidenciali$d a d$. Ya hemos visto que la confidencialidad es un deber secundario de conducta y que incluso el nuevo Código Civil y Comercial o Ley 26.994, califica la confidencialidad como un deber implícito que existe en toda negociación, y que su violación obliga a reparar el daño sufrido por la otra y, si ha obtenido una ventaja indebida de la información confidencial, deberá indemnizar a la otra parte en la medida de su propio enriquecimiento (art. 992). Pero también he señalado que es posible (y ello suele suceder frecuentemente) que las partes que comienzan un proceso negociador decidan celebrar de manera expresa y autónoma un convenio por el cual se obligan a no revelar información obtenida durante la negociación a terceras personas. Este es el convenio de confidencialidad.

El convenio de confidencialidad no puede considerarse un precontrato, si en tal instrumento se acordó únicamente lo relativo al intercambio de información de un proyecto, mas no se vislumbra un compromiso de concretar un negocio determinado ${ }^{58}$. En otras palabras, el convenio de confidencialidad solo puede generar responsabilidad si se viola el secreto revelado, pero claramente no obliga a contratar. Justamente, el conocimiento de lo confidencial es lo que permitirá a las partes determinar si es o no conveniente formalizar el negocio contractual.

E. Otro acuerdo que las partes suelen celebrar es la llamada minuta. La minuta es el convenio sobre ciertos aspectos de la contratación aún no culminada ${ }^{59}$, en el que se han acordado las cuestiones esen-

57 Jurisprudencia de la Cámara Nacional en lo Comercial, Sala D, Neptan S.A. vs. International Container Terminal Services y otros, 17 de febrero de 2010. Jurisprudencia Argentina, n. ${ }^{\circ} 2$, 65 (2010-III).

58 Jurisprudencia de la Cámara Nacional en lo Comercial, Sala F, Juan Carlos Mancinelli vs. Siemens IT Solutions and Services S.A. s/ ordinario, 11 de septiembre de 2011. 2012-B, La Ley, 365.

59 Alberto J. López-Fidanza, La responsabilidad en las tratativas precontractuales, Revista Doctrina Judicial, II.I. 3019 (2009). 
ciales, pero se ha diferido para más adelante el tratamiento de las accesorias $^{60}$.

Como puede verse, la minuta es un proyecto que puntualiza el resultado de las tratativas, pero que - en principio- carece de eficacia vinculante, justamente porque no se ha alcanzado un consentimiento pleno, mientras hay temas pendientes que, aunque sean accesorios, deben ser acordados. Es, por tanto, un acuerdo parcial, pero no es un contrato ${ }^{61}$.

F. Vinculada a la minuta aparece la teoría de la punktation, de origen germánico e incorporada en los códigos polaco y suizo de las obligaciones, la cual permite tener por concluido el contrato si se han acordado las cláusulas esenciales, a pesar de que las partes no se hayan puesto de acuerdo sobre todas las cuestiones.

Las XXIV Jornadas Nacionales de Derecho Civil, del Consejo Federal del Notariado Argentino, que reúnen a los profesores de todas las universidades de Argentina, celebradas el 26, 27 y 28 de septiembre de 2013 en la ciudad de Buenos Aires, declararon - por mayoría - que "es inconveniente incorporar la teoría de la punktation como regla general de los contratos" (conclusión 4) ${ }^{62}$.

Esa fue la ponencia que defendí en el trabajo de la comisión esta teoría es incorporada en el nuevo Código Civil y Comercial o Ley 26.994, en el art. 982-. Y mi crítica se basó no solo en el hecho de que se trata de una institución ajena a nuestra tradición jurídica, sino, y sobre todo, porque es inconveniente por el peligro que encierra.

En efecto, tomemos el ejemplo del contrato de compraventa. El nuevo Código Civil y Comercial o Ley 26.994 no expresa con claridad cuáles son sus elementos esenciales, sobre los cuales debería haber conformidad para establecer - luego de la debida integración - que hay contrato. Pero afirmemos que tales elementos esenciales son el objeto y el precio. También reconozcamos que se

60 Rubén S. Stiglitz, Contratos civiles y comerciales. Parte general I, 178, 2a ed., Editorial La Ley, Buenos Aires (2010).

61 Rubén S. Stiglitz, Contratos civiles y comerciales. Parte general I, 178, 2a ed., Editorial La Ley, Buenos Aires (2010).

62 Consejo Federal del Notariado Argentino, XXIV Jornadas Nacionales de Derecho Civil, 26, 27 y 28 de septiembre de 2013, Buenos Aires. Disponible en: http://www.cfna.org.ar/agenday-jornadas/jornadas-2013/xxiv-jornadas-nacionales-de-derecho-civil/ 
trata de un negocio causado (el nuevo Código Civil y Comercial exige - art. 1013 - que la causa exista en la formación del contrato y durante su celebración y subsistir durante su ejecución). ¿Es suficiente que haya acuerdo sobre el objeto y el precio, y que exista la causa, para que se tenga por concluido el contrato?

Me parece claro que si las partes reconocen que lo que hay es un acuerdo parcial, están afirmando que no hay todavía un acuerdo integral; por tanto, no hay contrato. En otras palabras, se está creando un contrato al que las partes todavía no califican de esa manera y que, además, nace incompleto, lo que necesitará la inmediata intervención del juez para integrarlo, en caso de desacuerdo de las partes. El propio Código o Ley 26.994 prevé que el contrato se integre con: “a) las normas indisponibles, que se aplican en sustitución de las cláusulas incompatibles con ellas; b) las normas supletorias; c) los usos y prácticas del lugar de celebración, en cuanto sean aplicables porque hayan sido declarados obligatorios por las partes o porque sean ampliamente conocidos y regularmente observados en el ámbito en que se celebra el contrato, excepto que su aplicación sea irrazonable" (art. 964).

Solo cuando haya un acuerdo integral, insisto, puede hablarse de contrato. Bien dispone el art. 1359 del Código Civil peruano que "no hay contrato mientras las partes no estén conformes sobre todas sus estipulaciones, aunque la discrepancia sea secundaria"63. A las partes les interesa no solamente acordar — siguiendo el ejemplo de la compraventa - lo que se quiere comprar o vender, o el precio a pagar. También les implica determinar el lugar de cumplimiento, la fecha de pago, si el pago será al contado o en cuotas, si la entrega de la cosa se hará antes o después del pago, si el saldo de precio será garantizado, si la garantía será real o personal, etcétera.

Todos estos problemas no pueden ser resueltos con la lacónica expresión que se lee en el art. 982 del nuevo Código Civil y Comercial argentino: de que en "la duda, el contrato se tiene por no concluido".

La buena fe que debe gobernar el contrato solo se puede garantizar cuando se lo tenga por concluido únicamente si las partes así lo manifiesten. Por tanto, a mi juicio, si se interrumpen las tratativas, aun cuando las partes hubiesen acordado las cuestiones esenciales

63 Perú, Decreto Legislativo 295, de 25 de julio de 1984, Código Civil. Disponible en: http://spij.minjus.gob.pe/CLP/contenidos.dll?f=templates\&fn=default-codcivil.htm\&vid=Ciclope:CLPdemo 
de un futuro contrato, estaremos ante un supuesto de responsabilidad precontractual. Al no existir un contrato cierto y definitivo, no puede haber responsabilidad contractual.

G. Finalmente, están los contratos preliminares. Estos son aquellos contratos que contienen un acuerdo sobre los elementos esenciales particulares que identifiquen el contrato futuro definitivo (conf. art. 994 del nuevo Código Civil y Comercial argentino).

Pero si estamos ante un contrato preliminar (también llamado precontrato), no es posible ya hablar de responsabilidad precontractual. Es cierto que no se ha alcanzado el contrato definitivo; sin embargo, el contrato preliminar es un contrato, un verdadero contrato, un contrato perfecto que genera una obligación de hacer $^{64}$, y cuyo incumplimiento acarreará una responsabilidad de tipo contractual ${ }^{65}$.

\section{LA REPARACIÓN POR LA RESPONSABILIDAD PRECONTRACTUAL. LAS TESIS DE IHERING Y FAGGELLA Y EL DERECHO ARGENTINO. LO QUE DEBE INDEMNIZARSE. EL FUNDAMENTO DE LA REPARACIÓN}

Es ineludible referirse a las tesis de Rudolph von Ihering y de Gabrielle Faggella cuando se trata de la reparación por la responsabilidad precontractual.

En la célebre monografía sobre la Culpa in contrahendo, Rudolf von Ihering ${ }^{66}$ sostuvo que era posible que una persona sufriera algún daño como consecuencia de una acción culposa realizada por otra, en el período previo a la formación del contrato, cuando se estaba contrayendo la relación contractual. De allí el nombre de culpa in contrahendo.

64 Jurisprudencia de la Cámara Nacional en lo Comercial, Sala E, Transportes Cadam S.A. vs. Coca-Cola FEMSA, 19 de octubre de 2006. Jurisprudencia Argentina, n. ${ }^{\circ}$, 82 (2007-II).

65 Jurisprudencia de la Cámara Nacional en lo Comercial, Sala D, Héctor M. Olivera vs. ICI Argentina S.A.I.C., 16 de noviembre de 2004. Jurisprudencia Argentina, n. ${ }^{\circ}$ 9, 68 (2005-II). Agustín Waisman, Repensando la responsabilidad precontractual, Revista El Derecho, tomo 205, 2, 943 (15 de diciembre de 2003).

66 Rudolf VOn Ihering, Della culpa in contrahendo, ossia del risarcimento del danno nei contratti nulli o non giunti a perfezione, Federico Procchi, trad., Jovene Editore, Napoli (2005). 
El jurista alemán no da mayor importancia a la buena fe pues afirma que quien ha causado el daño pudo haber obrado de buena fe. En cambio, valora la culpa en el obrar. La culpa in contrahendo es la violación de la obligación de diligencia que las partes deben observar en el transcurso de las relaciones anteriores a la celebración del contrato, con lo cual se evita que cada futuro contratante sea víctima de la negligencia del otro. Este período previo a la celebración del contrato nace con la emisión de la oferta; las tratativas anteriores quedan fuera del marco de responsabilidad y, por tanto, su interrupción no genera consecuencias de ningún tipo.

Para Ihering, la culpa in contrahendo es de naturaleza contractual, pues se ubica en el período de formación del contrato, que corre entre la emisión de la oferta y la concreción del contrato, y acarrea el deber de reparar el llamado daño al interés negativo; esto es, el daño sufrido a raíz de haber creído en la validez del negocio y que, por tanto, no habría sufrido si hubiese sabido que no era válido.

La visión de Ihering fue ampliada más tarde, y de manera sustancial, por Gabrielle Faggella ${ }^{67}$. Para el jurista italiano, el campo de la responsabilidad se extiende más allá del momento en que se formula la oferta, pues nace cuando los eventuales contratantes comienzan las tratativas del negocio, y finaliza cuando el contrato se perfecciona o se rompen las negociaciones entabladas.

Desde luego, la responsabilidad no será igual durante todo ese período y ello influirá en el resarcimiento del daño causado. A tal efecto, Faggella divide este tiempo en dos etapas: una que va desde el inicio de las tratativas hasta la oferta, y en el que las partes discuten e intercambian ideas, proyectan el contrato, y analizan sus cláusulas; otra, a partir de la oferta, en adelante. Incluso, la primera etapa es subdividida, a su vez, en dos: un primer tiempo que abarca el inicio de las conversaciones o tanteos; un segundo tiempo, que comprende el ordenamiento y proyecto de contrato.

En Argentina, a pesar de que la solución consagrada por el codificador fue la recepción de la tesis de culpa in contrahendo, desarrollada por Ihering, puede afirmarse que la responsabilidad no nace con la emisión de la oferta, sino antes, con el inicio de las tratativas previas, de acuerdo con lo que propone Faggella. Pero,

67 Gabrielle Faggella, Dei periodi precontrattuale e della loro vera e esatta costruzione scientifica, en Studi giuridici in onore di Carlo Fadda, t. III, Nabu Press, Napoli (1906). 
claro está, la intensidad de la responsabilidad se irá agravando a medida que avanzan las negociaciones, pues la intensidad de la propia relación también va creciendo ${ }^{68}$.

La exigencia de la buena fe durante las tratativas preliminares provoca la responsabilidad de quien las interrumpe injustificadamente. Ello ocurre cuando una de las partes lleva adelante las negociaciones, hasta el punto de inducir a la otra parte a confiar razonablemente en la conclusión del negocio y las abandona injustificadamente; esto es, cuando puede calificarse las tratativas de "avanzadas". Señala José Luis de los Mozos que esa falta de seriedad contraría el modelo de conducta en que consiste la buena fe, en sentido objetivo; sin embargo, añade, al valorarse un comportamiento, juega y se halla instrumentada como buena fe subjetiva, tanto desde el punto de vista activo como desde el pasivo ${ }^{69}$.

¿Qué es lo que se indemniza?

Como ya se dijo, y sin perjuicio de valorar el avance de las tratativas, lo que se indemniza es el daño al interés negativo, el cual comprende no solo el daño emergente (los gastos que hubiera realizado para concretar el contrato), sino también la ganancia frustrada por la no realización de otro contrato con un tercero ${ }^{70}$, siempre que acredite que este último fue desechado para poder cerrar el contrato que finalmente se frustró por culpa de la persona con quien se pretendía contratar ${ }^{71}$. Incluso, corresponde resarcir el daño moral si ha sido causado (arts. 1078 y 522 del Código Civil) ${ }^{72}$. Pero que quede claro, en los supuestos de responsabilidad precontractual no corresponde indemnizar el lucro cesante ${ }^{73}$, entendido como la ganancia esperada por el contrato que se estaba negociando

68 Jorge Mosset-Iturraspe, Contratos, 420, Editorial Rubinzal-Culzoni, Santa Fe (1995).

69 José Luis de Los Mozos, La buena fe en el anteproyecto de código europeo del contratos de la Academia de Pavía, en Tratado de la buena fe en el derecho, tomo II: doctrina extranjera y jurisprudencia, 257-276, 259, Marcos M. CórdobA, dir., Editorial La Ley, Buenos Aires (2004).

70 Rubén S. Stiglitz, Contratos civiles y comerciales. Parte general I, 151, 2a ed., Editorial La Ley, Buenos Aires (2010).

71 Jurisprudencia de la Cámara Nacional en lo Comercial, Sala E, Farley vs. L.R.I., 5 de junio de 1996. La Ley n. ${ }^{\circ} 39.026-S$. Este tribunal ha añadido en el fallo citado, para dar más claridad a la cuestión, que se resarce el menoscabo patrimonial sufrido en el proceso de formación del contrato.

72 Eduardo L. Gregorini-Clusellas, La responsabilidad precontractual y su reconocimiento, Revista La Ley, 4, 542 (2010-C).

73 Jurisprudencia de la Cámara Nacional en lo Comercial, Sala D, Bunker Diseños S.A. vs. IBM Argentina S.A., 2 de marzo de 2010. La Ley, 542 (2010-C); en Jurisprudencia Argentina, n. ${ }^{\circ}$ $6,10(2011-1)$. 
y que no se percibe como consecuencia de su frustración ${ }^{74}$, pues se trataría de un daño al interés positivo resarcible en caso de incumplimiento contractual ${ }^{75}$, contrato que — como se ha visto - no ha sido formalizado.

Teniendo en cuenta esta noción de daño al interés negativo, cabe hacer una breve digresión para señalar que no comparto el art. 991 del nuevo Código Civil y Comercial. Como se ha visto más arriba (apartado III), el nuevo Código prescinde de la idea del resarcimiento del daño al interés negativo, y dispone que lo que debe resarcirse es el daño que sufra el afectado por haber confiado, sin su culpa, en la celebración del contrato. ¿De qué daño se está hablando? ¿Podría reclamar el lucro cesante? ¿No sería acaso un daño que puede alegarse haber sufrido por confiar en la celebración del contrato? Y si fuera así, ¿qué diferencia habría entre la responsabilidad precontractual y contractual? Como se ve, la imprecisión de la norma genera importantes interrogantes que podrán causar incertidumbres notables.

Cerrada esta digresión, corresponde preguntarnos cuál es el fundamento de esta responsabilidad precontractual.

Ante todo, conviene recordar que el fundamento de la noción de responsabilidad civil se ha ido ampliando: de una responsabilidad fundada en la idea de culpa (responsabilidad subjetiva) a una responsabilidad fundada en factores de imputación objetivos.

En efecto, la teoría clásica descansaba sobre la idea de la responsabilidad subjetiva; esto es, el daño causado solo debía ser reparado si podía ser imputado al dolo, culpa o negligencia del supuesto dañador (art. 1109, Código Civil argentino). Por tanto, en esta tesis, si la víctima no aporta la prueba de la culpa del demandado, este no responde por el daño que aquella ha sufrido. Es, en definitiva, la propia víctima la que absorbe el daño.

La teoría moderna cambia la visión. No se preocupa tanto de la conducta dañadora, en la imputación moral que cabría hacer al sujeto autor del hecho, sino en la víctima, en la persona que sufre el daño. Así nace la llamada responsabilidad objetiva (art. 1113, Código

74 Rubén S. Stiglitz, Contratos civiles y comerciales. Parte general I, 151, 2a ed., Editorial La Ley, Buenos Aires (2010).

75 Jurisprudencia de la Cámara Nacional en lo Comercial, Sala E, Farley vs. L.R.I., 5 de junio de 1996. La Ley, n. ${ }^{\circ}$ 39.026-S. 
Civil argentino). Comienza a hablarse de una socialización del daño o, al menos, una socialización de su reparación. Pero es importante señalar que no cualquier daño genera una obligación de resarcir, pues se reconoce a esta atribución de responsabilidad un carácter excepcional: la responsabilidad objetiva solo existe en los casos que la ley contempla. En el régimen argentino, son casos previstos la garantía del principal, el riesgo creado por la cosa, la equidad y el exceso de la normal tolerancia entre vecinos ${ }^{76}$. Y considerando que la responsabilidad precontractual — como se verá seguidamente - no está regulada legalmente en Argentina, parece claro que no puede constituir un supuesto de responsabilidad objetiva ${ }^{77}$.

Cuando las negociaciones avanzan de manera tal que las partes puedan concebir una esperanza legítima de que el contrato será concluido, el desistimiento intempestivo, incausado y no justificado en cuestiones propias del negocio que se intentaba gestar, que formule una de ellas, no será inocuo ${ }^{78}$. En otras palabras, no cualquier interrupción de la negociación precontractual genera responsabilidad, pues habrá que hacer jugar diferentes principios que no se fundan exclusivamente en el avance de las tratativas; por un lado, el deber de no dañar, de raigambre constitucional, por otro el principio de la libertad contractual, y en ambos lados, el necesario obrar regular, no abusivo, y conforme al principio general de la buena fe.

Ahora, ¿cuál es el fundamento de esta responsabilidad precontractual?

En la legislación argentina no existe integralmente regulada la responsabilidad precontractual, sino que hay algunas normas dispersas que contemplan casos específicos, como el art. 1156 del Código Civil que contempla supuestos lícitos de retractación o caducidad de la oferta, pero que de todas maneras faculta al destinatario de ella que la ha aceptado a reclamar la reparación de los gastos o pérdidas sufridas.

Roberto H. Brebbia, quizás el autor argentino que más ha estudiado el tema, no duda en afirmar que, además de las respon-

76 Jorge Bustamante-Alsina, Teoría general de la responsabilidad civil, 925, Editorial AbeledoPerrot, Buenos Aires (1973).

77 Iván G. di Chiazza \& Pablo Augusto van Thienen, Tratativas precontractuales: delimitación de la figura, Revista La Ley, I, 588 (2012-B).

78 Guillermo A. Borda, Tratado de derecho civil. Obligaciones II, 1226, 10ª ed. Alejandro Borda, actual., Editorial La Ley, Buenos Aires (2012). 
sabilidades contractual y extracontractual, hay una tercera especie, autónoma, con rasgos diferenciales, que es la responsabilidad precontractual, que encontraría su fundamento justamente en esas normas dispersas en el Código Civil ${ }^{79}$.

Aprovechando un fallo dictado, afirma que la responsabilidad precontractual es aquella que se origina en razón de la comisión de un acto ilícito, por lo general culposo, sucedido en el curso de las tratativas previas a un contrato, del que deriva un daño al otro precontratante, generando el deber de resarcimiento. Y establece que sus caracteres específicos son: a) que exista un acto ilícito, entendiendo por tal no solo el acto culposo, sino también, el caso de ilicitud sin culpa, fundada mediatamente en la voluntad unilateral (v. gr., casos de los arts. 1155 y 1156, Cód. Civil); b) que el acto ilícito ocurra en el período precontractual, y tenga una conexión causal adecuada con las tratativas; c) y que los sujetos activos y pasivos de la relación de responsabilidad sean exclusivamente los precontratantes $^{80}$.

El recordado profesor rosarino precisa más su idea en el mismo trabajo y sostiene que el fundamento de la responsabilidad precontractual se encuentra en la culpa generada durante las tratativas, siempre que mantenga una relación de causalidad adecuada entre estas y el hecho ilícito. Añade que la culpa es el factor de atribución general de la responsabilidad civil, no siendo una excepción la responsabilidad in contrahendo. Y que hay supuestos en que la responsabilidad precontractual no se apoya en la culpa sino que deriva, en forma mediata, de la fuerza jurígena que posee la voluntad unilateral, como ocurre en los casos en que el destinatario hubiere aceptado la oferta ignorando la retractación, muerte o incapacidad del oferente (art. 1156, Código Civil argentino), o cuando no se cumple una oferta irrevocable (art. 1150, Código Civil argentino) ${ }^{81}$.

Sin embargo, a mi juicio, esta postura no puede ser admitida en el derecho argentino vigente, pues no hay una tercera especie de responsabilidad: la responsabilidad es contractual o extracontractual.

79 Roberto H. Brebia, Responsabilidad precontractual, 85 ss., Editorial La Rocca, Buenos Aires (1987).

80 Roberto H. Brebia, Responsabilidad precontractual en un caso de daño producido durante los preliminares de una compraventa, Revista La Ley, III, 92 (1993-C, 92).

81 Roberto H. Brebia, Responsabilidad precontractual en un caso de daño producido durante los preliminares de una compraventa, Revista La Ley, IV, 92 (1993-C, 92). 
¿Puede sostenerse que se trata de un supuesto de responsabilidad contractual? Se ha respondido afirmativamente, aduciendo que en este período precontractual, hay - en verdad - contrato. Ello sería así porque no es necesario el consentimiento expreso de la contraparte para que haya contrato, pues basta el consentimiento tácito, que puede resultar de signos inequívocos, esto es, hechos materiales o gestos indicativos con un significado propio e inconfundible, que le atribuyen las normas, los usos y las costumbres ${ }^{82}$.

Discrepo de esta postura. Que haya un acuerdo para iniciar negociaciones preliminares de ninguna manera puede ser asimilado a un contrato. La negociación deja abierta la posibilidad de no llegar a ningún acuerdo definitivo y, de hecho, muchas veces ello sucede sin acarrear consecuencia patrimonial alguna, pues las partes, habiendo obrado lealmente y de buena fe, no han logrado conformar la declaración de voluntad común que identifica al contrato. Claramente, no puede hablarse de una responsabilidad contractual pues, insisto, todavía no se ha celebrado contrato definitivo alguno. Como se ha dicho, no hay vínculo contractual; por tanto, lo que debe repararse es un daño que surge entre dos partes, que están vinculadas por una relación jurídica endeble, que no obliga como el contrato y solo impone deberes de conducta ${ }^{83}$.

Como se ha sostenido correctamente, darle a la responsabilidad precontractual categoría de responsabilidad contractual implica un incremento de los costos de transacción ${ }^{84}$, lo que carece de sustento legal. Por ello, coincido con quienes afirman que estamos ante un supuesto de responsabilidad extracontractual ${ }^{85}$. Bien se ha resuelto que las tratativas precontractuales no constituyen un contrato perfeccionado; pero ello no obsta para establecer que su ruptura intempestiva e injustificada puede generar responsabilidad por los

82 Constanza Bodini, Responsabilidad precontractual a la luz del derecho argentino, Revista El Derecho, 240, 1081 (13 de enero de 2011).

83 Noemí Lidia Nicolau, María del Pilar Hernández, Ariel Ariza \& Sandra Analía Frustagli, Fundamentos de derecho contractual, I, 373, Editorial La Ley, Buenos Aires (2009).

84 Iván G. di Chiazza \& Pablo Augusto van Thienen, Tratativas precontractuales: delimitación de la figura, Revista La Ley, II, 588 (2012-B).

85 Rubén S. Stiglitz, Contratos civiles y comerciales. Parte general I, 150, $2^{\text {a }}$ ed., Editorial La Ley, Buenos Aires (2010). Augusto H. L. Arduino, Culpa precontractual: condiciones para la generación de responsabilidad, Revista La Ley, 3, 365 (27 de marzo de 2012). Iván G. DI CHIAzzA \& Pablo Augusto van Thienen, Tratativas precontractuales: delimitación de la figura, Revista La Ley, 3, 588 (2012-B). Agustín Waisman, Repensando la responsabilidad precontractual, Revista El Derecho, tomo 205, 4, 943 (15 de diciembre de 2003). 
gastos en que se haya incurrido y por las expectativas frustradas, responsabilidad derivada del principio general de que nadie puede dañar a otro, siendo la responsabilidad emergente de carácter extracontractual ${ }^{86}$.

El fundamento habrá que buscarlo en algo ya dicho: la necesidad de obrar lealmente, conforme al principio general de la buena fe, $y$ ejercer los derechos de manera regular, no abusiva ${ }^{87}$. En efecto, el derecho a no contratar no puede ser ejercido de manera arbitraria. Como cualquier otro derecho debe ser ejercido de manera coherente al resto del ordenamiento jurídico, sin violentar sus principios rectores $^{88}$ (como el de la buena fe y el abuso del derecho, ya mencionados), y si ello no ocurre, deberán resarcirse los daños que se ocasionen.

Como se ve, no hay en el caso un factor de atribución objetiva de responsabilidad, sino subjetiva. No basta la mera interrupción de las tratativas para generar la responsabilidad, pues ello atentaría contra la libertad de contratar y de no contratar, sino que es necesario haber obrado - al menos - culposamente (de manera reprochable, negligente o descuidada) al interrumpirlas, luego de haber generado una confianza razonable en la otra parte en que la negociación iba a llegar a feliz término, pues existe siempre el deber de no dañar, de raigambre constitucional ${ }^{89}$.

Desde luego, la interrupción de la negociación dispuesta por una de las partes no será abusiva y, por tanto, no generará responsabilidad alguna, si ha habido conductas de la contraria que justificasen la interrupción, como la insuficiente información dada o la violación de un pacto de confidencialidad. En otras palabras, la interrupción no es injustificada si encuentra su causa en el comportamiento de la contraparte ${ }^{90} \mathrm{o}$ en la imposibilidad de llegar a

86 Jurisprudencia de la Cámara Nacional en lo Comercial, Sala D, Héctor M. Olivera vs. ICI Argentina S.A.I.C., 16 de noviembre de 2004. Jurisprudencia Argentina, n. ${ }^{\circ}$ 9, 68 (2005-II).

87 Jorge Mosset-Iturraspe, Contratos, 423, Editorial Rubinzal-Culzoni, Santa Fe (1995).

88 Iván G. Di Chiazza \& Pablo Augusto van Thienen, Tratativas precontractuales: delimitación de la figura, Revista La Ley, III, 588 (2012-B).

89 Se ha sostenido, y coincido con ello, que el fundamento de la responsabilidad precontractual está dado por la violación del principio general de la buena fe, la sanción del abuso del derecho y el deber de no dañar, pues son violaciones del ordenamiento jurídico. Agustín Waisman, Repensando la responsabilidad precontractual, Revista El Derecho, tomo 205, 3, 943 (15 de diciembre de 2003).

90 Iván G. Di Chiazza \& Pablo Augusto van Thienen, Tratativas precontractuales: delimitación de la figura, Revista La Ley, III, 588 (2012-B). 
un acuerdo definitivo, que podrá motivarse en diferentes razones (sea el precio, sea la calidad de la cosa que se promete, etc.).

Ahora si la interrupción de las tratativas ha sido abusiva y contraria al principio general de la buena fe y ello ha causado un daño, estamos ante un daño resarcible. En efecto, cabe recordar que los presupuestos de responsabilidad son cuatro: 1) el daño; 2) la relación de causalidad entre el daño y el hecho que lo causa, 3) la antijuridicidad del hecho y 4) el factor de atribución. Ahora si la parte negociadora que ha sido víctima de la interrupción intempestiva de las tratativas provocada por la otra ha sufrido un daño - que debe probarse-, resulta claro que ese daño ha sido causado por el hecho de la contraria, que al interrumpir la negociación injustificadamente, ha incurrido en una conducta abusiva ${ }^{91}$, desleal ${ }^{92}$ y contraria al principio general de la buena fe (y por tanto, antijurídica ${ }^{93}$ ), conducta culposa esta que genera un factor de atribución subjetivo ${ }^{94}$.

Por tanto, el factor de atribución es la culpa (o, con mayor razón, el dolo) en que ha incurrido el sujeto dañador, y hay correlación entre el acto (que en definitiva ha sido contrario a la buena fe) y el daño causado. Estamos, como puede advertirse, ante una situación idéntica a la que hay en los supuestos de responsabilidad extracontractual. Es atinado señalar, como enseña Rubén S. Stiglitz, que en la apreciación de la culpa en la responsabilidad precontractual, la columna vertebral del sistema se apoya en el principio general de la buena fe, receptado en el art. 1198 del Código Civil argentino, pues

91 Debe recordarse que el maestro peruano Carlos Fernández-Sessarego califica al abuso del derecho como ilícito sui generis. Carlos Fernández-Sessarego, Abuso del derecho, 5, $2^{\mathrm{a}}$ ed., Editorial Grijley, Lima (1999). Antes de ahora he seguido esta posición, AlEJAndro Borda, Teoría de los actos propios, 109, $4^{\mathrm{a}}$ ed., Ed. LexisNexis Abeledo-Perrot, Buenos Aires (1993).

92 Rubén S. Stiglitz, Contratos civiles y comerciales. Parte general I, 138, $2^{\text {a }}$ ed., Editorial La Ley, Buenos Aires (2010).

93 Jorge Mosset-Iturraspe, Contratos, 424, Editorial Rubinzal-Culzoni, Santa Fe (1995).

94 Jorge Mosset-Iturraspe se apoya en el abuso del derecho como fundamento de la responsabilidad precontractual, afirmando que "sobre la base de una concepción objetiva del acto abusivo, entendemos que no es condictio sine qua non para que se origine la responsabilidad precontractual que se demuestre la existencia de culpa o dolo en quien produce la ruptura intempestiva o arbitraria de las tratativas". Jorge Mosset-Iturraspe, Contratos, 426, Editorial Rubinzal-Culzoni, Santa Fe (1995). A mi juicio, determinar que ha existido un ejercicio abusivo del derecho implica tomar en cuenta la conducta y valorarla. Como se ha visto, el factor de atribución objetivo responde a otros parámetros como, por citar algunos ejemplos, el riesgo de la cosa o la garantía del principal. 
la buena fe es la directiva que impera en toda la vida del contrato, desde las tratativas precontractuales ${ }^{95}$.

Y si se llegara a prescindir de la culpa como factor de atribución y la responsabilidad se derivara de la aplicación de una disposición legal que imponga el deber de resarcir, el fundamento de la responsabilidad es la disposición legal indicada pero nunca una supuesta responsabilidad precontractual que carece de sustento legal.

95 Rubén S. Stiglitz, Contratos civiles y comerciales. Parte general I, 146, 2a ed., Editorial La Ley, Buenos Aires (2010). 


\section{BIBLIOGRAFÍA}

\section{Libros}

Alterini, Atilio Aníbal, Contratos civiles, comerciales, de consumo: teoría general, Editorial Abeledo-Perrot, Buenos Aires (1998).

Borda, Alejandro, Teoría de los actos propios, $4^{\mathrm{a}}$ ed., Ed. LexisNexis Abeledo-Perrot, Buenos Aires (1993).

Borda, Guillermo A., Tratado de derecho civil, parte general II, $14^{\mathrm{a}}$ ed., Guillermo J. BordA, actual., Editorial La Ley, Buenos Aires (2013).

Borda, Guillermo A., Tratado de derecho civil. Obligaciones II, $10^{\text {a }}$ ed. Alejandro BordA, actual., Editorial La Ley, Buenos Aires (2012).

Brebbia, Roberto H., Responsabilidad precontractual, Editorial La Rocca, Buenos Aires (1987).

Bustamante-Alsina, Jorge, Teoría general de la responsabilidad civil, Editorial AbeledoPerrot, Buenos Aires (1973).

Díez-Picazo y Ponce de León, Luis, La doctrina de los propios actos, un estudio crítico sobre la jurisprudencia del Tribunal Supremo, Bosch Casa Editorial, Barcelona (1963).

Fernández-Sessarego, Carlos, Abuso del derecho, $2^{\mathrm{a}}$ ed., Editorial Grijley, Lima (1999).

IHERING, Rudolf von, Della culpa in contrahendo, ossia del risarcimento del danno nei contratti nulli o non giunti a perfezione, Federico Procchi, trad., Jovene Editore, Napoli (2005).

Llambías, Jorge Joaquín, Tratado de derecho civil, parte general II, Editorial Perrot, Buenos Aires (2012).

Lorenzetti, Ricardo Luis, Consumidores, Editorial Rubinzal-Culzoni, Santa Fe (2003).

Los Mozos, José Luis De, El principio de la buena fe, sus aplicaciones prácticas en el derecho civil español, Bosch Casa Editorial, Barcelona (1965).

Martínez-Botos, Raúl, Medidas cautelares, Editorial Universidad, Buenos Aires (1996).

Mosset-Iturraspe, Jorge, Contratos, Editorial Rubinzal-Culzoni, Santa Fe (1995).

Nicolau, Noemí lidia; Hernández, María del Pilar; Ariza, Ariel \& Frustagli, Sandra Analía, Fundamentos de derecho contractual, Editorial La Ley, Buenos Aires (2009).

Romero-Coloma, Aurelia M., Problemática de la buena fe en el ordenamiento jurídico, Editorial Tapia, Madrid (1990).

Stiglitz, Rubén S., Contratos civiles y comerciales. Parte general I, 2a ed., Editorial La Ley, Buenos Aires (2010). 


\section{Contribución en obra colectiva}

Calegari de Grosso, Lidia E., El principio de la buena fe en relación con las nuevas formas de propiedad en las comunidades cerradas, en Tratado de la buena fe en el derecho, tomo I: doctrina nacional, 553-568, Marcos M. Córdoba, dir., Editorial La Ley, Buenos Aires (2004).

Corral-Talciani, Hernán, La aplicación jurisprudencial de la buena fe objetiva en el ordenamiento civil chileno, en Tratado de la buena fe en el derecho, tomo II: doctrina extranjera y jurisprudencia, 205-224, Marcos M. CórdobA, dir., Editorial La Ley, Buenos Aires (2004). Versión actualizada disponible en: http://www.udp.cl/descargas/facultades_carreras/derecho/pdf/investigaciones/ Cuadernos_de_analisis_Coleccion_Derecho_Privado/N3_Temas_contratos/ aplicacion_jurisprudencia_ordenamientocivilchileno_hernanCorral.pdf

Faggella, Gabrielle, Dei periodi precontrattuale e della loro vera e esatta costruzione scientifica, en Studi giuridici in onore di Carlo Fadda, t. III, Nabu Press, Napoli (1906).

Kiper, Claudio Marcelo, La buena fe y el sistema registral inmobiliario. El principio de la buena fe registral, en Tratado de la buena fe en el derecho, tomo I: doctrina nacional, 589-604, Marcos M. Córdoba, dir., Editorial La Ley, Buenos Aires (2004).

LorenzetTi, RicArdo Luis, Esquema de una teoría sistémica del contrato, La Ley, tomo 1999-E, 1168-1185, sección Doctrina, Buenos Aires (diciembre de 1999).

Los Mozos, José Luis de, La buena fe en el anteproyecto de código europeo del contratos de la Academia de Pavía, en Tratado de la buena fe en el derecho, tomo II: doctrina extranjera y jurisprudencia, 257-276, MARCos M. CórdobA, dir., Editorial La Ley, Buenos Aires (2004).

Villaça-Azevedo, Marcos de Almeida, La buena fe objetiva y los deberes de ella derivados, en Tratado de la buena fe en el derecho, tomo II: doctrina extranjera y jurisprudencia, 129-154, Marcos M. Córdoba, dir., Editorial La Ley, Buenos Aires (2004).

\section{Revistas}

Alterini, Atilio Aníbal, Los pilares del contrato moderno, 10 Revista de Responsabilidad Civil y Seguros, 5, 3-19 (2008).

Arduino, Augusto H.L., Culpa precontractual: condiciones para la generación de responsabilidad, Revista La Ley (27 de marzo de 2012).

Bianchi, Enrique Tomás \& Iribarne, Héctor Pedro, El principio general de la buena fe $y$ la doctrina 'venire contra factum proprium non valet', Revista El Derecho, tomo $108,851-862$.

Bodini, Constanza, Responsabilidad precontractual a la luz del derecho argentino, Revista El Derecho (13 de enero de 2011).

Brebita, Roberto H., Responsabilidad precontractual en un caso de daño producido durante los preliminares de una compraventa, Revista La Ley (1993-C, 92). 
Chiazza, Iván G. di \& Thienen, Pablo Augusto van, Tratativas precontractuales: delimitación de la figura, Revista La Ley (2012-B).

Compagnucci, Rubén H., La doctrina de los propios actos y la declaración tácita de la voluntad, Revista La Ley (1985-A).

Compagnucci de Caso, Rubén H., Responsabilidad precontractual, Revista La Ley (1985-A).

Compagnucci de Caso, Rubén H., Responsabilidad precontractual (Desarrollo general del tema), Revista La Ley (2006-E).

Gregorini-Clusellas, Eduardo L., La responsabilidad precontractual y su reconocimiento, Revista La Ley (2010-C).

LóPEZ-FidAnZA, Alberto J., La responsabilidad en las tratativas precontractuales, Revista Doctrina Judicial (2009).

LORENZETTI, RicARDO L., La responsabilidad precontractual como atribución de los riesgos de la negociación, Revista La Ley (1993-B).

Minoprio, CÉsar CARlos, El boleto de compraventa, el ejercicio abusivo del derecho y la prohibición de ir en contra de los propios actos, Revista del Notariado (1975, julio-agosto).

Morello, Augusto Mario \& Stiglitz, Rubén S., La doctrina del acto propio, Revista La Ley (1984-A).

Waisman, Agustín, Repensando la responsabilidad precontractual, Revista El Derecho, tomo 205, 2, 943 (15 de diciembre de 2003).

\section{Normatividad internacional}

Chile, Decreto con Fuerza de Ley 1, 16 de mayo de 2000, Código Civil. Disponible en: http://www.leychile.cl/Navegar?idNorma $=172986$

Instituto Internacional para la Unificación del Derecho Privado, UNIDROIT, Principios Unidroit sobre los Contratos Comerciales Internacionales 2004. Disponible en: http://www.unidroit.org/spanish/principles/contracts/principles2004/ blackletter2004.pdf

Italia, Regio Decreto 262, 16 marzo 1942, Codice Civile. Disponible en: http://www. altalex.com/index.php?idnot $=34794$

Perú, Decreto Legislativo 295, de 25 de julio de 1984, Código Civil. Disponible en: http://spij.minjus.gob.pe/CLP/contenidos.dll?f=templates\&fn=default-codcivil. htm\&vid=Ciclope:CLPdemo

Portugal, Decreto-Lei 47.344, de 25 de Novembro de 1966, Código Civil, actualizado até à Lei 59/99, de 30 de Junho de 1999. Disponible en: http://www.wipo.int/ wipolex/es/details.jsp?id=7991 


\section{Normatividad argentina}

Constitución de la Nación Argentina, 1 de mayo de 1853. Disponible en: http:// www.senado.gov.ar/bundles/senadoparlamentario/pdf/institucional/ constitucionNac1853.pdf

Constitución de la Nación Argentina, 22 de agosto de 1994. Disponible en: http://www. senado.gov.ar/bundles/senadoparlamentario/pdf/institucional/constitucion_ nacional_argentina.pdf

Ley 340, 25 de septiembre de 1869, Código Civil. Disponible en: http://www.infoleg.gov. ar/infolegInternet/anexos/105000-109999/109481/texact.htm

Ley 2.637, 1 de mayo de 1890, Código de Comercio. Disponible en: http://www.infoleg. gov.ar/infolegInternet/anexos/105000-109999/109500/texact.htm

Ley 17.711, 22 de abril de 1968, Código Civil, modificaciones. Disponible en: http://www. infoleg.gob.ar/infolegInternet/verNorma.do?id=103603

Ley 20.266, 10 de abril de 1973, Martilleros, condiciones habilitantes. Disponible en: http://www.infoleg.gob.ar/infolegInternet/verNorma.do?id=56724

Ley 24.449, 23 de diciembre de 1994, Ley de Tránsito. Disponible en: http://www.infoleg. gob.ar/infolegInternet/anexos/0-4999/818/texact.htm

Ley 25.028, 1 de diciembre de 1999, Régimen legal de martilleros y corredores. Disponible en: http://infoleg.mecon.gov.ar/infolegInternet/verNorma.do?id=61719

Ley 26.994, 1 de octubre de 2014, Código Civil y Comercial de la Nación. Disponible en: http://www.infoleg.gob.ar/infolegInternet/verNorma.do?id=235975

\section{Casos}

Jurisprudencia de la Cámara Nacional de Apelaciones en lo Civil y Comercial Federal, Sala 2, A. M. H. vs. Obra Social de la Unión del Personal Civil de la Nación s/inc. de apelación de medida cautelar, 27 de diciembre de 2012, 253, El Derecho, 307.

Jurisprudencia de la Cámara Nacional en lo Civil, Sala A, Soria Luis Santos vs. Jet Paq S.A., 27 de diciembre de 2011.

Jurisprudencia de la Cámara Nacional en lo Civil, Sala B, Könisberg vs. Almagro Construcciones S.A., 24 de septiembre de 1986.

Jurisprudencia de la Cámara Nacional en lo Civil, Sala F, Aldana-Acosta vs. CambaFernández, 14 de agosto de 1986.

Jurisprudencia de la Cámara Nacional en lo Comercial, Sala D, Bunker Diseños S.A. vs. IBM Argentina S.A., 2 de marzo de 2010.

Jurisprudencia de la Cámara Nacional en lo Comercial, Sala D, Héctor M. Olivera vs. ICI Argentina S.A.I.C., 16 de noviembre de 2004.

Jurisprudencia de la Cámara Nacional en lo Comercial, Sala D, Neptan S.A. vs. International Container Terminal Services y otros, 17 de febrero de 2010.

Jurisprudencia de la Cámara Nacional en lo Comercial, Sala E, Farley vs. L.R.I., 5 de 
junio de 1996.

Jurisprudencia de la Cámara Nacional en lo Comercial, Sala E, Transportes Cadam S.A. vs. Coca-Cola FEMSA, 19 de octubre de 2006.

Jurisprudencia de la Cámara Nacional en lo Comercial, Sala F, Juan Carlos Mancinelli vs. Siemens IT Solutions and Services S.A., 11 de septiembre de 2011.

\section{Documentos, informes, reportes}

Consejo Federal del Notariado Argentino, XXIV Jornadas Nacionales de Derecho Civil, 26, 27 y 28 de septiembre de 2013, Buenos Aires. Disponible en: http:// www.cfna.org.ar/agenda-y-jornadas/jornadas-2013/xxiv-jornadas-nacionalesde-derecho-civil/ 
